\title{
PENGARUH DIGITAL MARKETING TERHADAP ONLINE PURCHASE DECISION PADA PLATFORM BELANJA ONLINE SHOPEE
}

\author{
Reminta Lumban Batu'), Tiar Lina Situngkir ${ }^{2)}$, Indah Krisnawati' ${ }^{3)}$, Sherliana Halim ${ }^{4}$ \\ Program Studi Manajemen, Universitas Singaperbangsa Karawang \\ e-mail :reminta.lumban@fe.unsika.ac.id
}

\begin{abstract}
Abstrak
Pemanfaatan teknologi telah mendorong pertumbuhan bisnis karena berbagai informasi yang dapat disajikan melalui hubungan jarak jauh. E-commerce adalah salah satu kemajuan teknologi informasi, dimana suatu sistem melayani pembeli secara online melalui media jaringan komputer. Banyaknya e-commerce di Indonesia mendorong perusahaan harus memiliki strategi pemasaran yang menarik agar konsumen mengunjungi platform $e$ commerce yang akhirnya konsumen akan melakukan keputusan pembelian. Tujuan penelitian ini adalah untuk mengetahui pengaruh Digital Marketing terhadap Online Purchase Decision pada Shopee. Penelitian ini dilakukan dengan menggunakan metode deskriptif dan verifikatif. Teknik sampling penelitian ini simple random sampling dengan menggunakan rumus Slovin. Jenis data yang digunakan dalam penelitian ini adalah data primer dan data sekunder. Data diolah menggunakan menggunakan PLS (Partial Least square). Hasil penelitian ini membuktikan bahwa website, search engine marketing, web banner, social media, affiliate marketing, email marketing dan online purchase decision berpengaruh positif dan signifikan terhadap Online Purchase Decision.
\end{abstract}

Kata kunci: E-commerce, Pemasaran Digital, Keputusan Pembelian Online

\begin{abstract}
Utilization of technology has driven business growth due to various information that can be presented through long distance relationships. E-commerce is one of the advances in information technology, where a system serves online buyers through computer network media. The number of e-commerce in Indonesia encourages companies to have an attractive marketing strategy so that consumers visit the e-commerce platform which ultimately consumers will make a purchase decision. The purpose of this study was to determine the effect of Digital Marketing on Online Purchase Decisions on Shopee. This research was conducted using descriptive and verification methods. The sampling technique of this study was simple random sampling using the Slovin formula. The type of data used in this study are primary data and secondary data. Data is processed using PLS (Partial Least square). The results of this study prove that websites, search engine marketing, web banners, social media, affiliate marketing, email marketing and online purchase decisions have a positive and significant effect on Online Purchase Decisions
\end{abstract}

Key words: E-commerce, Digital Marketing, Online Purchase Decision 


\section{PENDAHULUAN}

Internet adalah sistem global dari seluruh jaringan komputer yang saling terhubung satu dengan lainnya yang dapat digunakan untuk saling berkomunikasi (Sumber: Termasmedia.com, diakses pada 2 Desember 2019). Internet telah membawa perubahan yang sangat berarti dalam berbagai aspek yang ada didalam kehidupan manusia khususnya dalam berbisnis (Wijaya, 2018). Bisnis adalah suatu kegiatan yang dilakukan oleh individu atau kelompok organisasi yang melakukan aktivitas penjualan, produksi, distribusi, pembelian atau pertukaran barang/ jasa dengan tujuan untuk memperoleh keuntungan atau laba (Nilakandi, 2019). Bisnis digital yaitu bisnis yang memanfaatkan teknologi sebagai kegiatan pemasaran yang dilaksanakan secara elektornik melalui jaringan internet. Pemasaran digital dikatakan sebagai sisi pemasaran e-commerce yang terdiri dari kerja perusahaan untuk mengomunikasikan, mempromosikan serta menjual barang/jasa melalui internet (Suryadi, 2018).

Perkembangan e-commerce $\mathrm{di}$ Indonesia semakin meningkat, secara perlahan masyarakat mulai meninggalkan kebiasan berbelanja secara konvensional dan beralih berbelanja secara online. Ecommerce dijadikan solusi sebagai media jual beli yang dapat meghemat waktu dan biaya.

Kemudahan $e$ commerce menjangkau pasar lokal maupun mancanegara membuat masyarakat semakin tertarik pada jual-beli di e-commerce (Sumber: teamwork.id, diakses pada 2 Dseember 2019).

Fashion adalah produk terlaris dan menguntungkan bagi e-commerce. kategori fashion yang dimaksud meliputi kosmetik dan produk perawatan tubuh seperti health and beauty. Industri fashion di platform $e$ commerce semakin diminati. Hal ini didorong oleh gaya belanja milenial yang kerap menghabiskan uangnya di produkproduk kecantikan dan pakaian jadi (Ulya, 2019). Berikut adalah data pembelian dalam kategori fashion pada perusahan $E$ commerce pada tahun 2018 .
Tabel 1

Pembelian Kategori Fashion Pada $E$ Commerce Indonesia

\begin{tabular}{lc}
\hline E-commerce & Indeks \\
\hline Lazada & $19 \%$ \\
\hline Tokopedia & $12 \%$ \\
\hline Blibli & $17 \%$ \\
\hline Bukalapak & $16 \%$ \\
\hline Shopee & $24 \%$ \\
\hline
\end{tabular}

Sumber: dailysocial.id, diakses pada 10 Oktober 2018

Berdasarkan Tabel 1 menunjukkan bahwa Shopee menjadi pilihan utama keputusan konsumen dalam pembelian online kategori fashion pada tahun 2018. Hal tersebut karena Shopee memiliki strategi pemasaran yang luar biasa sehingga konsumen lebih memilih melakukan keputusan pembelian pada e-commerce Shopee dibandingkan dengan e-commerce lainnya. Banyaknya e-commerce di Indonesia menjadikan persaingan yang ketat pada setiap platformnya. Berikut persaingan e-commerce Indonesia berdasarkan pengunjung web di kuartal IV 2018.

\section{Tabel 2}

Persaingan $E$-Commerce di Indonesia

\begin{tabular}{lc}
\hline E-Commerce & Pengunjung Website \\
\hline Lazada & 58 Juta \\
\hline Tokopedia & 168 Juta \\
\hline Blibli & 43 Juta \\
\hline Bukalapak & 116 Juta \\
\hline Shopee & 67 Juta \\
\hline
\end{tabular}

Sumber: www.CNBCIndonesia.com, diakses pada 2 Novermber 2019

Berdasarkan Tabel 2 menunjukkan bahwa persaingan e-commerce di Indonesia semakin ketat. Tokopedia menduduki posisi pertama dengan pengunjung web terbanyak. E-commerce Shopee baru beroperasi di Indonesia Tahun 2015 namun pengunjung web Shopee sudah dapat disejajarkan dengan e-commerce besar lainnya. Hal tersebut dikarenakan Shopee memiliki strategi yang berhasil menarik konsumen untuk menunjungi webnya. 
Tabel 3

Top Brand Indeks E-commerce Di Indonesia

\begin{tabular}{llllll}
\hline $\begin{array}{l}\text { E- } \\
\text { commerce }\end{array}$ & TBI & TBI & TBI & TBI & TBI \\
\hline Lazada & - & $41,9 \%$ & $18,0 \%$ & $31,8 \%$ & $31,6 \%$ \\
\hline Tokopedia & $1,2 \%$ & $7,2 \%$ & $13,4 \%$ & $18,5 \%$ & $13,4 \%$ \\
\hline Blibli & - & - & - & $14,7 \%$ & $6,6 \%$ \\
\hline Bukalapak & $0,7 \%$ & $6,6 \%$ & $6,8 \%$ & $8,7 \%$ & $12,7 \%$ \\
\hline Shopee & - & - & - & $8 \%$ & $15,6 \%$ \\
\hline Sur
\end{tabular}

Sumber: www.topbrand-award.com, diakses pada 10 Oktober 2019

Berdasarkan Tabel 3 menunjukkan bahwa meskipun Shopee terbilang baru beroperasi di Indonesia namun Shopee berhasil memasuki top brand indeks di Indonesi. Hal ini karena Shopee telah berhasil dalam melakukan pemasaran secara digital kepada konsumen Indonesia sehingga menjadi e-commerce yang terpercaya dan menjadi tujuan utama masyarakat Indonesia dalam berbelanja online.

Banyak perusahaan E-commerce Indonesia yang memiliki strategi pemasaran untuk menarik masyarakat. Perlu diketahui dengan jelas bahwa terdapat beberapa hal yang dapat mempengaruhi keputusan pembelian konsumen. Shopee merupakan perusahaan E-commerce yang tepat sebagai obyek penelitian untuk mengetahui hal yang mempengaruhi keputusan pembelian konsumen. Berdasarkan latar belakang masalah diatas, peneliti tertarik untuk mengambil judul "Pengaruh Digital Marketing terhadap Online Purchase Decision pada Shopee".

Tujuan penelitian ini untuk mengetahui gambaran digital marketing pada Shopee, untuk mengetahui gambaran online purchase decision pada Shopee dan untuk mengetahui seberapa besar digital marketing mempengaruhi online purchase decision.

\section{RUMUSAN MASALAH}

Berdasarkan latar belakang, maka rumusan masalah penelitian ini yaitu

1. Bagaimana gambaran digital marketing pada Shopee

2. Bagaimana gambaran online purchase decision pada Shopee
3. Seberapa besar digital marketing mempengaruhi online purchase decision.

\section{TINJAUAN PUSTAKA}

\section{E-commerce}

Menurut Laudon (2013) E-commerce adalah media perdangan elektorik yang memiliki karakteristik atau sifat-sifat tertentu. E-commerce adalah pembelian, penjualan dan pemasaran barang serta jasa melalui sistem elektronik seperti radio, televisi dan jaringan computer atau internet (Jony Wong, 2010:33 dalam Aco \& Endang, 2017).

\section{Digital Marketing}

Digital marketing adalah penggunaan internet dan penggunaan teknologi interaktif lain untuk membuat dan menghubungkan informasi antara perusahaan dan konsumen yang telah teridentifikasi (Hisam sam, 2018). Pemasaran internet atau digital dapat berupa web site, search engine marketing, web banner, social networking, viral marketing, e-mail marketing dan affiliate marketing (Salya, 2010: 4 dalam Ulil Azmi, 2016).

\section{Website}

Suatu halaman web yang saling berhubungan dan dapat diakses melalui halaman depan (home page) menggunakan sebuah browser dan jaringan internet yang berisikan kumpulan informasi (Sumber: www.indowebsite.id, diakses pada 24 November 2019)

\section{Search Engine Marketing}

Pemanfaatan business directory untuk menjaring pengunjung bekerjasama dengan search engine (Anshari \& Mahani, 2018). strategi pemasaran digital yang digunakan untuk meningkatkan visibilitas situs web di halaman hasil mesin pencari (Sukandar, 2019).

\section{Web Banner}

Bagian yang tidak bergerak dalam dokumen web/blog yang berupa tulisan besar atau gambar untuk mempromosikan sesuatu ataupun ajakan dalam berbagai hal. Banner 
dibuat atau di desain semenarik dan secantik mungkin untuk menarik perhatian pengunjung website (Sumber: www.creohouse.co.id, diakses pada 26 November 2019)

\section{Social Network}

Situs dimana setiap orang bisa membuat web page pribadi, kemudian terhubung dengan orang lain untuk berbagi informasi dan berkomunikasi seperti Facebook, Twitter dan Instagram (Sebayang, 2016).

\section{E-mail Marketing}

Penargetan konsumen melalui email biasanya dilakukan oleh para pelaku bisnis online. Email marketing dikirimkan kepada calon pelanggan yang belum pernah membeli produk dan kepada konsumen yang memang sudah menjadi pelanggan di bisnis tersebut (Iskandar, 2019)

\section{Affiliate Marketing}

Kegiatan bermitra dengan organisasi/ perusahaan lain dan website-website untuk mencapai keuntungan bersama dari sebuah kerjasama untuk mempromosikan produk atau layanan (Anshari \& Mahani, 2018).

\section{Online Purchase Decision}

Kotler dan Keller (2014:188) Keputusan pembelian konsumen adalah membeli merek yang paling disukai dari berbagai alternatif yang ada, tetapi dua faktor bisa berada antara niat pembelian dan keputusan pembelian (Dahlan, 2017). Menurut (Fika, 2015) dimensi keputusan pembelian yaitu:

1. Pengenalan kebutuhan (need recognition), yaitu melibatkan informasi berkenaan dengan keputusan tentang di mana produk tersebut harus dibeli dan kapan pembelian harus terjadi.

2. Pencarian informasi (information research), yaitu seorang yang tertarik akan suatu produk mungkin akan mencari lebih banyak informasi.

3. Evaluasi berbagai alternatif (alternative evaluation), yaitu dimana konsumen menggunakan informasi untuk mengevaluasi merek-merek alternatif dalam satu susunan pilihan.

4. Keputusan pembelian (purchase decision), yaitu pengambilan keputusan pembeli dimana konsumen benarbenar membeli produk.

5. Perilaku pasca pembelian (postpurchase behaviour), yaitu dimana konsumen mengambil tindakan lebih lanjut setelah membeli berdasarkan kepuasan yang mereka rasakan.

\section{METODE PENELITIAN}

Penelitian ini menggunakan jenis penelitian data Kuantitatif. Metode kuantitatif dilakukan dengan cara survey untuk mengetahui respon dari subyek penelitian. Populasi pada penelitian ini yaitu followers akun instagram Shopee. Pengambilan sampel dilakukan dengan menggunakan simple random sampling. Teknik pengumpulan data dalam penelitian ini adalah studi kepustakaan, penyebaran kuesioner dan dokumentasi. Pengujian penelitian ini menggunakan PLS (Partial Least square). Teknik analisis data penelitian ini menggunakan analisis deskripstif dan verifikatif. Analisis deskriptif dengan menggunakan kuisioner yang disebarkan kepada responden agar diperoleh deskripsi tentang variabel-variabel penelitian. Teknik data verifikatif yang digunakan ialah dengan SEM - PLS. Penelitian ini menggunakan bantuan program SmartPLS3 untuk menghubungkan antara variabel laten dengan variabel manifest. 


\section{HASIL DAN PEMBAHASAN}

Hasil Uji Instrumen

Pengujian Outer Model

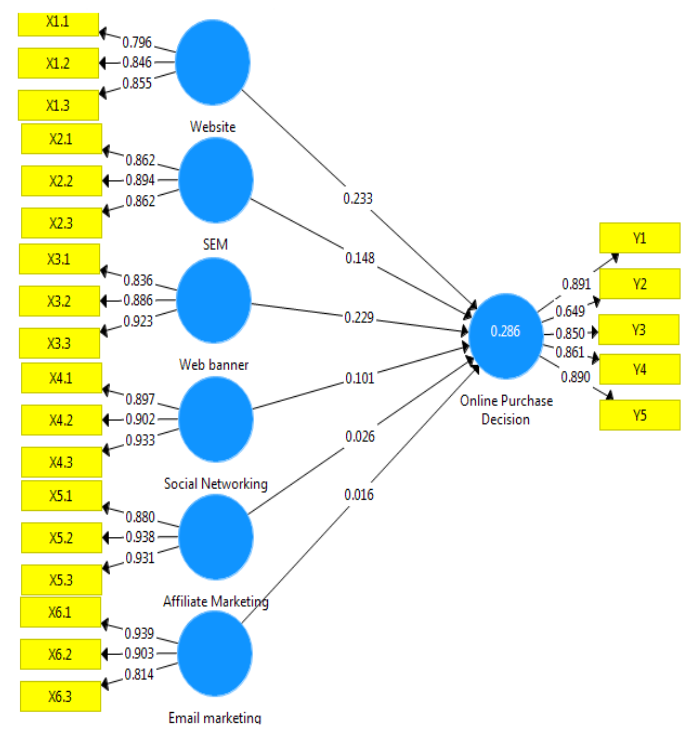

Sumber: Hasil Pengolahan Data, 2019

Gambar 1

Diagram Jalur Full Model

Berdasarkan Gambar1 menunjukkan bahwa website berpengaruh positif sebesar 23,3\% terhadap online purchase decision, search engine marketing berpengaruh positif sebesar $14,8 \%$ terhadap online purchase decision, web banner berpengaruh positif sebesar 22,9\% terhadap online purchase decision, social network berpengaruh positif sebesar 10,1\% terhadap online purchase decision, affiliate marketing berpengaruh positif sebesar $2,6 \%$ terhadap online purchase decision dan email marketing berpengaruh positif sebesar 1,6\% terhadap online purchase decision.
TABEL 4

NILAI OUTER LOADINGS

\begin{tabular}{|c|c|c|c|c|c|}
\hline & (o) & (M) & $\begin{array}{c}\text { (STD } \\
\text { EV) }\end{array}$ & $\begin{array}{c}\text { (|O/STR } \\
\text { ERR } \mid)\end{array}$ & P V \\
\hline $\begin{array}{l}\mathrm{X} 1.1 \\
\leftarrow \\
\mathrm{WS}\end{array}$ & 0,796 & 0,781 & 0,082 & 9,679 & 0,000 \\
\hline $\begin{array}{l}\mathrm{X} 1.2 \\
\leftarrow \\
\mathrm{WS}\end{array}$ & 0,846 & 0,842 & 0,044 & 19,194 & 0,000 \\
\hline $\begin{array}{l}\mathrm{X} 1.3 \\
\leftarrow \\
\mathrm{WS}\end{array}$ & 0,855 & 0,852 & 0,053 & 16,109 & 0,000 \\
\hline $\begin{array}{l}\mathrm{X} 2.1 \\
\leftarrow \\
\text { SEM }\end{array}$ & 0,862 & 0,863 & 0,051 & 16,892 & 0,000 \\
\hline $\begin{array}{l}\text { X2.2 } \\
\leftarrow \\
\text { SEM }\end{array}$ & 0,894 & 0,889 & 0,048 & 18,583 & 0,000 \\
\hline $\begin{array}{l}\text { X2.3 } \\
\leftarrow \\
\text { SEM }\end{array}$ & 0,862 & 0,856 & 0,051 & 16,777 & 0,000 \\
\hline $\begin{array}{l}\text { X3.1 } \\
\leftarrow \\
\text { WEB }\end{array}$ & 0,836 & 0,825 & 0,058 & 14,432 & 0,000 \\
\hline $\begin{array}{l}\text { X3.2 } \\
\leftarrow \\
\text { WB }\end{array}$ & 0,886 & 0,878 & 0,061 & 14,541 & 0,000 \\
\hline $\begin{array}{l}\mathrm{X} \text { X3.3 } \\
\leftarrow \\
\text { WB }\end{array}$ & 0,923 & 0,927 & 0,021 & 44,935 & 0,000 \\
\hline $\begin{array}{l}\mathrm{X} 4.1 \\
\leftarrow \\
\text { SN }\end{array}$ & 0,897 & 0,896 & 0,077 & 11,675 & 0,000 \\
\hline $\begin{array}{l}\mathrm{X} 4.2 \\
\leftarrow \\
\mathrm{SN}\end{array}$ & 0,902 & 0,889 & 0,107 & 8,458 & 0,000 \\
\hline $\begin{array}{l}\text { X4.3 } \\
\leftarrow \\
\text { SN }\end{array}$ & 0,933 & 0,926 & 0,09 & 10,393 & 0,000 \\
\hline $\begin{array}{l}\text { X5.1 } \\
\leftarrow \\
\text { AM }\end{array}$ & 0,88 & 0,87 & 0,117 & 7,546 & 0,000 \\
\hline $\begin{array}{l}\text { X5.2 } \\
\leftarrow \\
\mathrm{AM}\end{array}$ & 0,938 & 0,931 & 0,116 & 8,079 & 0,000 \\
\hline $\begin{array}{l}\text { X5.3 } \\
\leftarrow \\
\text { AM }\end{array}$ & 0,931 & 0,922 & 0,107 & 8,666 & 0,000 \\
\hline
\end{tabular}

Sumber: Hasil Pengolahan Data, 2019

Berdasarkan Tabel 4 menunjukkan bahwa semua indikator dari masing-masing variabel website, search engine marketing, web banner, social media, affiliate marketing, email marketing dan online purchase decision memiliki Loading Factor diatas 0,5 sehingga diketahui bahwa semua indikator dari variabel website, search engine marketing, web banner, social media, affiliate marketing, email marketing dan online purchase decision valid 
sebagai indicator untuk mengukur konstrak/ variabel masing-masing.

TABEL 5

COMPOSITE RELIABILITY (CR)

\begin{tabular}{|l|c|c|}
\hline & $\begin{array}{c}\text { Composite } \\
\text { Reliability }\end{array}$ & $\begin{array}{c}\text { Cronbach's } \\
\text { Alpha }\end{array}$ \\
\hline Website (X1) & 0,871 & 0,783 \\
\hline SEM (X2) & 0,905 & 0,884 \\
\hline $\begin{array}{l}\text { Web Banner } \\
\text { (X3) }\end{array}$ & 0,913 & 0,858 \\
\hline $\begin{array}{l}\text { Social } \\
\text { Network (X4) }\end{array}$ & 0,936 & 0,898 \\
\hline $\begin{array}{l}\text { Affiliate } \\
\text { Marketing } \\
\text { (X5) }\end{array}$ & 0,941 & 0,906 \\
\hline $\begin{array}{l}\text { Email } \\
\text { Marketing } \\
\text { (X6) }\end{array}$ & 0,917 & 0,862 \\
\hline $\begin{array}{l}\text { Online } \\
\text { Purchase } \\
\text { Decision (Y) }\end{array}$ & 0,918 & 0,886 \\
\hline
\end{tabular}

Sumber: Hasil Pengolahan Data, 2019

Berdasarkan Tabel 5 menunjukkan bahwa nilai composite reliability untuk masing-masing variabel diatas 0,7 . Artinya indikator dari masing-masing variabel website, search engine marketing, web banner, social media, affiliate marketing, email marketing dan online purchase decision dapat dikatakan memiliki reliabilitas atau keterandalan yang baik sebagai alat ukur.

Tabel 6

Average Variance Extracted (Ave)

\begin{tabular}{|l|c|}
\hline & $\begin{array}{c}\text { Average Variance } \\
\text { Extracted (AVE) }\end{array}$ \\
\hline Website (X1) & 0,693 \\
\hline SEM (X2) & 0,761 \\
\hline Web Banner (X3) & 0,778 \\
\hline Social Networking (X4) & 0,83 \\
\hline Affiliate Marketing (X5) & 0,841 \\
\hline Email Marketing (X6) & 0,787 \\
\hline $\begin{array}{l}\text { Online Purchase } \\
\text { Decision (Y) }\end{array}$ & 0,694 \\
\hline
\end{tabular}

Sumber: Hasil Pengolahan Data, 2019

Berdasarkan Tabel 6 menunjukkan bahwa nilai AVE pada semua variabel diatas 0,5 artinya variabel dikatakan valid secara konvergen. Nilai AVE pada variabel website
(X1) sebesar 0,693 artinya secara rata-rata $69,3 \%$ informasi yang terdat pada masingmasing indikator dapat terwakili melalui variabel laten website. Nilai AVE pada variabel search engine marketing (X2) sbesar 0,761 artinya secara rata-rata $76,1 \%$ informasi yang terdapat pada masing-masing indikator dapat terwakili melalui variabel laten search engine marketing. nilai AVE pada variabel web banner (X3) sebesar 0,778 artinya secara ratarata $77,8 \%$ informasi yang terdat pada masingmasing indikator dapat terwakili melalui variabel laten web banner. Nilai AVE pada variabel social networking (X4) sebesar 0,83 artinya secara rata-rata $83 \%$ informasi yang terdat pada masing-masing indikator dapat terwakili melalui variabel laten social marketing. Nilai AVE pada variabel affiliate marketing (X5) sebesar 0,841 artinya secara rata-rata $84,1 \%$ informasi yang terdat pada masing-masing indikator dapat terwakili melalui variabel laten affiliate marketing. Nilai AVE pada variabel email marketing (X6) sebesar 0,787 artinya secara rata-rata $78,7 \%$ informasi yang terdat pada masing-masing indikator dapat terwakili melalui variabel laten email marketing. Nilai AVE pada variabel online purchase decision (Y) sebesar 0,694 artinya secara rata-rata $69,4 \%$ informasi yang terdat pada masing-masing indikator dapat terwakili melalui variabel laten online purchase decision.

TABEL 7 CROSS LOADING

\begin{tabular}{|c|c|c|c|c|c|c|c|}
\hline & $\begin{array}{c}W S \\
(\mathrm{X} 1 \\
)\end{array}$ & $\begin{array}{c}S E \\
M \\
(\mathrm{X} 2 \\
)\end{array}$ & $\begin{array}{c}W B \\
(\mathbf{X 3} \\
)\end{array}$ & $\begin{array}{c}S N \\
(\mathrm{X} 4 \\
)\end{array}$ & $\begin{array}{c}A M \\
(\mathrm{X} 5 \\
)\end{array}$ & $\begin{array}{c}E M \\
\text { (X6 } \\
\text { ) }\end{array}$ & $\begin{array}{c}\boldsymbol{O P} \\
\boldsymbol{D} \\
(\mathbf{Y})\end{array}$ \\
\hline $\begin{array}{l}\mathrm{X} 1 \\
.1\end{array}$ & $\begin{array}{l}0,7 \\
96\end{array}$ & $\begin{array}{l}0,3 \\
72\end{array}$ & $\begin{array}{l}0,1 \\
21\end{array}$ & $\begin{array}{l}0,1 \\
82\end{array}$ & $\begin{array}{l}0,0 \\
72\end{array}$ & $\begin{array}{c}0,2 \\
09\end{array}$ & \\
\hline $\begin{array}{l}\mathrm{X} 1 \\
.2\end{array}$ & $\begin{array}{r}0,8 \\
46\end{array}$ & $\begin{array}{c}0,4 \\
1\end{array}$ & $\begin{array}{l}0,2 \\
93\end{array}$ & $\begin{array}{l}0,2 \\
65\end{array}$ & $\begin{array}{l}0,2 \\
47\end{array}$ & & \\
\hline $\begin{array}{l}\mathrm{X} 1 \\
.3\end{array}$ & $\begin{array}{c}0,8 \\
55\end{array}$ & $\begin{array}{c}0,2 \\
7\end{array}$ & $\begin{array}{l}0,3 \\
16\end{array}$ & $\begin{array}{l}0,4 \\
09\end{array}$ & $\begin{array}{l}0,2 \\
66\end{array}$ & $\begin{array}{l}0,2 \\
56\end{array}$ & \\
\hline $\begin{array}{l}\mathrm{X} 2 \\
.1\end{array}$ & $\begin{array}{l}0,3 \\
35\end{array}$ & $\begin{array}{l}0,8 \\
62\end{array}$ & $\begin{array}{l}0,3 \\
06\end{array}$ & $\begin{array}{l}0,3 \\
24\end{array}$ & & & \\
\hline $\begin{array}{c}\mathrm{X} 2 \\
2\end{array}$ & $\begin{array}{l}0,2 \\
96\end{array}$ & 0,8 & 0,2 & 0,0 & 0,8 & $\begin{array}{l}0,3 \\
94\end{array}$ & $\begin{array}{l}0,3 \\
27\end{array}$ \\
\hline $\begin{array}{l}\mathrm{X} 2 \\
.3\end{array}$ & $\begin{array}{l}0,4 \\
54\end{array}$ & $\begin{array}{l}0,8 \\
62\end{array}$ & $\begin{array}{l}0,3 \\
74\end{array}$ & $\begin{array}{l}0,2 \\
15\end{array}$ & $\begin{array}{c}0,4 \\
14\end{array}$ & $\begin{array}{l}0,4 \\
28\end{array}$ & \\
\hline $\mathrm{X} 3$ & 0,2 & 0,3 & 0,8 & 0,2 & $\begin{array}{l}0,5 \\
0,5\end{array}$ & $\begin{array}{l}0,4 \\
04\end{array}$ & $\begin{array}{l}0,3 \\
03\end{array}$ \\
\hline$\frac{1}{X 3}$ & $\frac{16}{0,2}$ & 0,1 & $\begin{array}{l}36 \\
0,8\end{array}$ & $\frac{44}{0,1}$ & $\frac{98}{0,5}$ & $\frac{04}{0,3}$ & $\frac{03}{0,3}$ \\
\hline .2 & 2 & 77 & 86 & 95 & 05 & 92 & 34 \\
\hline
\end{tabular}




\begin{tabular}{|l|c|c|c|c|c|c|c|}
$\mathrm{X} 3$ & 0,3 & 0,3 & 0,9 & 0,3 & 0,5 & 0,4 & 0,4 \\
.3 & 48 & 39 & 23 & 61 & 56 & 92 & 19 \\
\hline $\mathrm{X} 4$ & 0,3 & 0,2 & 0,3 & 0,8 & 0,3 & 0,3 & 0,2 \\
.1 & 22 & 68 & 47 & 97 & 29 & 37 & 81 \\
\hline $\mathrm{X} 4$ & 0,3 & 0,1 & 0,1 & 0,9 & 0,2 & 0,2 & 0,2 \\
.2 & 58 & 69 & 93 & 02 & 12 & 79 & 58 \\
\hline $\mathrm{X} 4$ & 0,3 & 0,2 & 0,3 & 0,9 & 0,2 & 0,3 & 0,2 \\
.3 & 05 & 09 & 01 & 33 & 56 & 21 & 9 \\
\hline $\mathrm{X} 5$ & 0,2 & 0,3 & 0,5 & 0,2 & 0,8 & 0,3 & 0,2 \\
.1 & 27 & 64 & 86 & 04 & 8 & 55 & 57 \\
\hline $\mathrm{X} 5$ & 0,2 & 0,4 & 0,5 & 0,2 & 0,9 & 0,4 & 0,3 \\
.2 & 63 & 68 & 96 & 96 & 38 & 73 & 38 \\
\hline $\mathrm{X} 5$ & 0,1 & 0,4 & 0,5 & 0,2 & 0,9 & 0,4 & 0,3 \\
.3 & 83 & 07 & 34 & 95 & 31 & 6 & 03 \\
\hline $\mathrm{X} 6$ & 0,2 & 0,4 & 0,4 & 0,2 & 0,5 & 0,9 & 0,2 \\
.1 & 1 & 15 & 47 & 77 & 06 & 39 & 54 \\
\hline $\mathrm{X} 6$ & 0,3 & 0,4 & 0,4 & 0,2 & 0,4 & 0,9 & 0,2 \\
.2 & 24 & 14 & 26 & 78 & 22 & 03 & 96 \\
\hline $\mathrm{X} 6$ & 0,1 & 0,3 & 0,4 & 0,3 & 0,3 & 0,8 & 0,2 \\
.3 & 92 & 94 & 31 & 61 & 31 & 14 & 65 \\
\hline & 0,3 & 0,3 & 0,3 & 0,2 & 0,2 & 0,2 & 0,8 \\
$\mathrm{Y} 1$ & 22 & 28 & 01 & 1 & 57 & 17 & 91 \\
\hline & 0,2 & 0,2 & 0,4 & 0,2 & 0,2 & 0,3 & 0,6 \\
$\mathrm{Y} 2$ & 09 & 12 & 62 & 93 & 81 & 02 & 49 \\
\hline & 0,3 & 0,3 & 0,3 & 0,2 & 0,3 & & 0,8 \\
$\mathrm{Y} 3$ & 71 & 55 & 56 & 57 & 66 & 0,3 & 5 \\
\hline & 0,3 & 0,2 & 0,2 & 0,3 & 0,2 & 0,1 & 0,8 \\
$\mathrm{Y} 4$ & 77 & 04 & 32 & 02 & 11 & 85 & 61 \\
\hline & 0,4 & 0,3 & 0,3 & 0,2 & 0,2 & 0,2 & 0,8 \\
$\mathrm{Y} 5$ & 12 & 84 & 2 & 06 & 4 & 6 & 9 \\
\hline
\end{tabular}

Sumber: Hasil Pengolahan Data, 2019

Berdasarkan Tabel 7 menunjukkan bahwa indikator X1.1-X1.3 lebih tinggi berkorelasi dengan variabel website (X1) dibandingkan dengan variabel lainnya. Indikator X2.1-X2.3 lebih tinggi berkorelasi dengan variabel search engine marketing (X2) dibandingkan dengan variabel lainnya. Indikator X3.1-X3.3 lebih tinggi berkorelasi dengan variabel web banner (X1) dibandingkan dengan variabel lainnya. Indikator X4.1-X4.3 lebih tinggi berkorelasi dengan variabel social networking (X4) dibandingkan dengan variabel lainnya. Indikator X5.1-X5.3 lebih tinggi berkorelasi dengan variabel affiliate marketing (X5) dibandingkan dengan variabel lainnya. Indikator X6.1-X6.3 lebih tinggi berkorelasi dengan variabel email marketing (X6) dibandingkan dengan variabel lainnya. Indikator Y1-Y5 lebih tinggi berkorelasi dengan variabel online purchase decision $(\mathrm{Y})$ dibandingkan dengan variabel lainnya. Nilai cross loading indikator yang lebih tinggi terhadap variabelnya dibandingkan dengan variabel lain menunjukkan bahwa discriminant validity dalam penelitian ini sudah sesuai.
TABEL 8 COLLINEARITY STATISTIC (VIF)

\begin{tabular}{|l|r|}
\hline & \multicolumn{1}{|r|}{ VIF } \\
\hline $\mathrm{X} 1.1$ & 1,644 \\
\hline $\mathrm{X} 1.2$ & 1,826 \\
\hline $\mathrm{X} 1.3$ & 1,521 \\
\hline $\mathrm{X} 2.1$ & 1,828 \\
\hline $\mathrm{X} 2.2$ & 2,273 \\
\hline $\mathrm{X} 3.1$ & 2,081 \\
\hline $\mathrm{X} 3.2$ & 1,871 \\
\hline $\mathrm{X} 3.3$ & 2,347 \\
\hline $\mathrm{X} 4.1$ & 2,569 \\
\hline $\mathrm{X} 4.2$ & 2,454 \\
\hline $\mathrm{X} 4.3$ & 2,82 \\
\hline $\mathrm{X} 5.1$ & 3,379 \\
\hline $\mathrm{X} 5.2$ & 2,439 \\
\hline $\mathrm{X} 5.3$ & 3,438 \\
\hline $\mathrm{X} 6.1$ & 3,455 \\
\hline $\mathrm{X} 6.2$ & 4,48 \\
\hline $\mathrm{X} 6.3$ & 3,577 \\
\hline $\mathrm{Y} 1$ & 1,744 \\
\hline $\mathrm{Y} 2$ & 3,253 \\
\hline $\mathrm{Y} 3$ & 1,356 \\
\hline $\mathrm{Y} 4$ & 2,452 \\
\hline $\mathrm{Y} 5$ & 3,118 \\
\hline
\end{tabular}

Sumber: Hasil Pengolahan Data, 2019

Uji multicolliniearity dilakukan untuk mengetahui hubungan antar indikator. Untuk mengetahui apakah indikator formatif mengalami multicolliniearity dengan mengetahui nilai VIF. Berdasarkan Tabel nilai VIF < 10 artinya dapat dikatakan bahwa indikator tersebut tidak terjadi multicolliniearity.

TABEL 9

R SQUARE

\begin{tabular}{|c|c|c|}
\hline & $\begin{array}{c}\boldsymbol{R} \\
\text { Square }\end{array}$ & $\begin{array}{c}\text { R Square } \\
\text { Adjusted }\end{array}$ \\
\hline $\begin{array}{c}\text { Online } \\
\text { Purchase } \\
\text { Decision }\end{array}$ & 0,286 & 0,24 \\
\hline
\end{tabular}

Sumber: Hasil Pengolahan Data, 2019

Menurut Vincenco (2010) Kriteria nilai $R$ Square sebesar 0,67 (kuat), 0.33 (moderat), 0,19 (lemah). Menurut chin (1998), nilai $R$ Square dikatakan (kuat) jika nilai sebesar 0,67, dikatakan (moderat) jika nilai sebesar 0.33 dan dikatakan (lemah) jiak nilai sebesar 0,19. 
Berdasarkan Tabel 9 hasil dari $R$ Square (R2) diatas menghasilkan nilai online purchase decision sebesar 0,286 maka nilai $R$ Square dikatakan (moderat).

Hasil penelitian sejalan dengan logika teori pembahasan sebelumnya yang menyebutkan bahwa dalam digital marketing yang meliputi Website, Search Engine Marketing, Web Banner, Social Media dan affiliate Marketing sesuai dengan penelitian (Wati, 2013) dalam Deavaj at al. (2003) yang menyatakan terdapat keterkaitan antar variabel marketing Online terhadap keputusan pembelian, hal itu dibuktikan yakni keputusan pembelian secara online dipengaruhi oleh beberapa faktor yaitu 1) efisiensi sebuah pencarian meliputi waktu yang cepat, mudah dalam penggunaan dan usaha pencarian yang mudah 2) value yang meliputi harga bersaing dan kualitas terbaik 3) interaksi meliputi informasi, load time, keamanan dan navigasi.

Salah satu variabel penelitian inipun didukung oleh Jurnal Penelitian (Ghafiki \& Setyorini, 2017) yang menyatakan bahwa pengolahan data secara simultan kualitas website berpengaruh secara signifikan terhadap keputusan pembelian.

Hasil penelitian ini bertolak belakang dengan kesimpulan pada jurnal penelitian (Wandanaya, 2012) yang menyatakan bahwa budaya penduduk Indonesia untuk membeli barang online masih rendah, dikarenakan mereka lebih suka belanja dengan konvensional. Penelitian ini membuktikan dengan hasil nilai kontinum online purchase desicion yang sesuai data penelitian adalah termasuk dalam kategori tinggi

\section{KESIMPULAN DAN SARAN}

Berdasarkan hasil penelitian yang berkaitan dengan rumusan masalah dalam penelitian ini, maka dapat diambil kesimpulan sebagai berikut:

1. Gambaran digital marketing diukur melalui variabel website, search engine marketing, web banner, social networking serta affiliate marketing.
Pengaruh tertinggi oleh Website. Hal ini menunjukkan adanya penilaian baik dari responden mengenai website yang memberikan informasi dan promosi kepada konsumen. Sedangkan pengaruh terendah adalah $e$-mail marketing.

2. Gambaran variabel online purchase desicion diukur melalui dimensi need recognition, information search, alternative evaluation, purchase decision dan postpuchase desicioin. Pengaruh tertinggi yaitu need recognition. Hal ini menunjukkan adanya penilaian baik dari responden mengenai need recognition membuat konsumen melakukan online purchase decision. pengaruh terendah adalah information research.

3. Terdapat pengaruh positif digital marketing terhadap online purchase desicion

\section{UCAPAN TERIMA KASIH}

Peneliti bersyukur dengan selesainya penelitian ini, dan peneliti mengucapkan terimakasih kepada seluruh pihak yang telah membantu dan berpartisipasi dalam penelitian ini sehingga terlaksana dengan baik, lancar, dan sukses.

\section{DAFTAR PUSTAKA}

Aco, A., \& Endang, A. H. (2017). Analisis Bisnis E-Commerce pada Mahasiswa Universitas Islam Negeri Alauddin Makassar.

Anshari, M. F., \& Mahani, S. E. (2018). Pengaruh Digital Marketing dan Sales Promotion terhadap Impulse Buying pada Situs Berrybenka . com ( Studi Kasus pada Masyarakat Kota Bandung ), 11741179.

Dahlan. (2017). Bab ii kajian pustaka, kerangka pemikiran, dan hipotesis 2.1., 25-94.

Fika, A. (2015). pengaruh Keamanan, Kemudahan, dan Resiko Kinerja terhadap Keputusan Pembelian secara Online di Tokopedia.

Ghafiki, R., \& Setyorini, R. (2017). Pengaruh Kualitas Website Terhadap Keputusan 
Pembelian Pada Situs Bukalapak.Com the Impact of Website Quality To Purchase Decision on Bukalapak.Com, $4(1), 678-686$.

Hisam sam. (2018). \&quot;Digital

Marketing\&quot; Pengertian Menurut

Para Ahli \&amp; ( Manfaat - Kelebihan

- Kekurangan ).

Iskandar, C. A. (2019). Apa Itu Email

Marketing? 12 April 2019. Retrieved

from

https://www.wartaekonomi.co.id/read2

23504/apa-itu-email-marketing.html

Nilakandi, Z. (2019). Pengertian Bisnis

Beserta Fungsi, tujuan dan Jenis-Jenis

Bisnis Secara Lengkap. 4 Oktober

2019. Retrieved from

https://www.nesabamedia.com/pengerti an-bisnis/

Sebayang, E. K. (2016). Social Media VS

Social Network. 31 Oktober 2016.

Retrieved from

https://www.kompasiana.com/evikristin

/5816e1388d7e61b31916f0c2/social-

media-vs-social-network?page $=$ all

Sukandar, C. A. (2019). Apa Itu Search

Engine Marketing? 4 April 2019.

Retrieved from

https://www.wartaekonomi.co.id/read2

22345/apa-itu-search-engine-

marketing.html

Suryadi, D. (2018). Mendongkrak

Akselerasi Bisnis Via Transformasu

Digital. 24 Oktober 2018, 66.

Ulil Azmi, M. (2016). Pengaruh Program

Komunikasi Pada Digital Marketing

Dan Sales Promotion Terhadap Impulse

Buying Pada Konsumen Situs

Lazada.Co.Id. Program Studi Ilmu

Komunikasi Falsafah Dan Peradaban

Paramadina.

Ulya, F. N. (2019). Fashion Jadi Produk

Terlaris dan Menguntungkan bagi E-

Commerce. 12 Juli 2019. Retrieved

from

https://money.kompas.com/read/2019/0

7/12/193100126/fashion-jadi-produk-

terlaris-dan-menguntungkan-bagi-e-

commerce

Wandanaya, A. B. (2012). TERHADAP

KEPUTUSAN PEMBELIAN

PRODUK Di era globalisasi serta

teknologi yang terus berkembang saat

ini pemasaran dapat menerapkan suatu

teknologi baru yang cepat dan mampu menjangkau konsumen secara global dalam waktu singkat dan dana yang tidak terlalu be, 5(2).

Wati, N. (2013). Analisis Pengaruh Harga, Kualitas Produk, Dan Marketing Online Terhadap Keputusan Pembelian Serta Pengaruhnya Pada Kepuasan Konsumen. Management, 1-16.

Wijaya, M. (2018). Pengaruh Internet untuk

Bisnis dan masa Depan. 7 Desmber 2018.

Retrieved from

https://www.kompasiana.com/moniccaw/ 5c0a782e6ddcae289a6942e5/pengaruhinternet-untuk-bisnis-dan-masadepan?page $=$ all 
